\title{
Agricultural Geography Analysis of Carob Tree (Ceratonia siliqua L.) from Turkey
}

\author{
Güven Şahin $^{1^{*}}$, Nuran Taşlıgil ${ }^{2}$
}

${ }^{1}$ Department of Geography, Institute of Social Sciences, Istanbul University, 34116 Istanbul, Turkey ${ }^{2}$ Department of Geography, Faculty of Arts and Sciences, Marmara University, 34722 Istanbul, Turkey A R T I C LE IN F O

\section{Article history:}

Received 08 September 2016

Accepted 21 November 2016

Available online, ISSN: 2148-127X

Keywords:

Carob Tree

Harnup

Ceratonia siliqua $\mathrm{L}$.

Carob products

Agricultural geography

A B S T R A C T

Carob tree (Ceratonia siliqua L.) is one of the oldest trees in the world and has been cultivated from civilization of Ancient Persia, especially on the Mediterranean coasts, till nowadays. The fruit of the carob tree (carob bean) are attracting attention in recent years due among others to tits rich nutritional value and use as a substitute and/or alternative for cocoa. Although it has higher sugar content than sugar beet and sugar cane, it is a food that also lowers cholesterol. In addition to its fruit, the plant has interesting morphological qualities. Deep root system of carob tree allows high productivity even in draught conditions; it is an ideal plant in the fight against erosion and one of the most preferred plants while establishing fire-resistant forests. Additionally, because 2016 was declared the International Year of Pulses, it is necessary to draw attention to the carob tree since it is a typical pulse plant. The status of Turkey, as the $5^{\text {th }}$ carob producer in the world, was analysed in this context, in terms of Agricultural Geography. The existing and necessary practices in carob production are discussed based on the data from the studies conducted in Antalya and Mersin in 2015 and previous ones.

${ }^{*}$ Corresponding Author:

E-mail: guven.sahin@ogr.iu.edu.tr

\section{Introduction}

Legumes (Fabaceae) are one of the three important plant groups for human nutrition along with grains and oil seeds. Legumes are a very wide family and contain about 700 species and 18.000 varieties including herbaceous and woody plants such as beans (Phaseolus vulgaris), broad beans (Vicia faba), chickpeas (Cicer arietinum), soybean (Glycine max), vetch (Vicia sativa), lentil (Lens culinaris), cowpea (Vigna unguiculata), fenugreek (Trigonella foenum-graecum), pea (Pisum sativum), tamarind (Tamarindus indica), acacia (Acacia nilotica), peanut (Arachis hypogaea), clovers (Trifolium), ervil (Vicia ervilia), sweet peas (Lathyrus) and, bird's foot (Lotus corniculatus). $22 \%$ of the vegetable protein in human nutrition and $38 \%$ in animal one are provided by legumes (Özdem, 2012: 1). On the other hand, legumes are not common as grains and oil seeds in agricultural life. In the world 720.669 .449 ha of grains and 299.051.897 ha of oil seeds were harvested in 2014, in contrast to 85.655.492 ha of legumes (FAO, 2016).

To draw attention to legumes, Turkey and Pakistan engaged in various efforts. As a result, 2016 was declared the "International Year of Pulses (IYP)" by the $68^{\text {th }}$ UN General Assembly to emphasize food security, environmental issues, sustainable rural development and balanced nutrition. Within the IYP context, the prime goals are:
- Increasing awareness concerning the effects of legumes on nutrition, and agricultural sustainability for food security and nutrition to increase global production and consumption of legumes and ensuring the balance of supply and demand;

- Allowing access to the market and removing commercial obstacles to facilitate local, national and international trade;

- And enabling cooperation between countries and the private sector as stakeholders. (For more information and images concerning the subject, visit able the web site for the International Year of Pulses: http://www.fao.org/pulses-2016/en/ (Last access: 12.09.2016).)

To create awareness concerning legumes and to draw attention to their importance, a series of national and international activities are planned for the year 2016. In this context, legumes are discussed in various categories (Agriculture, Archaeobotany, History, Geography, Economy, Sociology, etc.). Carob tree (Ceratinoa siliqua L.) is an endemic species of the Mediterranean climate. It is one of the legumes that has been planted and used by humans for the longest time in the world, with another legume called apple-ring acacia or ana tree [Faidherbia albida (Delile) A. Chey]. It was estimated that this plant 
has been used since 4000 - 5000 B.C. in Egypt, to feed animals and make wine, and it has been frequently mentioned in human history (Anonymous, 1979; Demirtaş, 2007). Carob tree has a very long cultural history and is still economically important due to its various fields of use. Both the carob pulp and beans are used for various functions in traditional and industrial activities in many countries.

This study discusses the presence of carob tree in Turkey and its economic value in terms of agricultural geography in the context of 2016 International Year of Pulses, which was declared due to Turkey's efforts. This plant was used for various purposes in Turkey for a very long time, and it started garnering attraction in recent years. However, serious deficiencies in the industry forced the establishment of an integrated "Carob Production Plan". Thus, the technical visits that we conducted to Antalya and Mersin in 2015, and the observations and producer-consumer interviews we made constitute the basic data of our study. Additionally, we also emphasized the local products obtained from Carob and their potentials as Geographical Signs in light of field studies and literature reviews. Moreover, we have prepared the map of geographical distribution of carob in Turkey by using the ArcGIS software, version 10.2, according to statistical data of Turkstat, FAO and City Directorates of Agriculture.

\section{Botanical and Agro-Ecological Properties of Carob Tree}

Carob's name in Latin, "Ceratonia siliqua L." is derived from the Greek "keras" (horn) and Latin "siliqua" (small). Etymologically, Carob is called by many names in various languages, such as "kharuv" in Hebrew, "kharrub" in Arabic, "carruba" in Italian, "johannisbrot, karob" in German, "algarrobo, garrofera" in Spanish, "carob, locust bean" in English, "caroubier" in French, "charaoupi, keration" in Greek, "alfarrobeira" in Portuguese and "harnup, harup, hirnap, ballı boynuz" in Turkish. The plant is also known in Europe as "St. John's Bread; German: Johannisbrot). Legend says that Job survived in the desert by eating carob fruit (Bronstein, 2013).

Carob tree is a member of the legume family (Fabaceae) and is a scrub tree in the form of an evergreen shrub/tree that is spread over the area where the Mediterranean climate is dominant. In addition, classical scrubs such as Olea europea var. sylvestris, Myrtus communis, Phillyrea latifolia, Pistacia terebinthus, Pistacia lentiscus, Styrax officinalis; oak varieties such as $Q$. frainetto, $Q$. infectoria, $Q$. coccifera and $Q$. cerris are also encountered in the areas where the carob tree lives. Carob species is found in the form of a shrub - tree (3-4 $\mathrm{m}$ of height) where $P$. brutia, $P$. pinea, $P$. halepensis, Juniperus phoenica and Cupressus sempervirens var. horizontalis constitute forests, while it becomes dominant and reaches $10-15 \mathrm{~m}$ of height where these species are destroyed, and form large clusters (Günal,1999). Carob trees that are maintained in culture can even reach $20 \mathrm{~m}$.

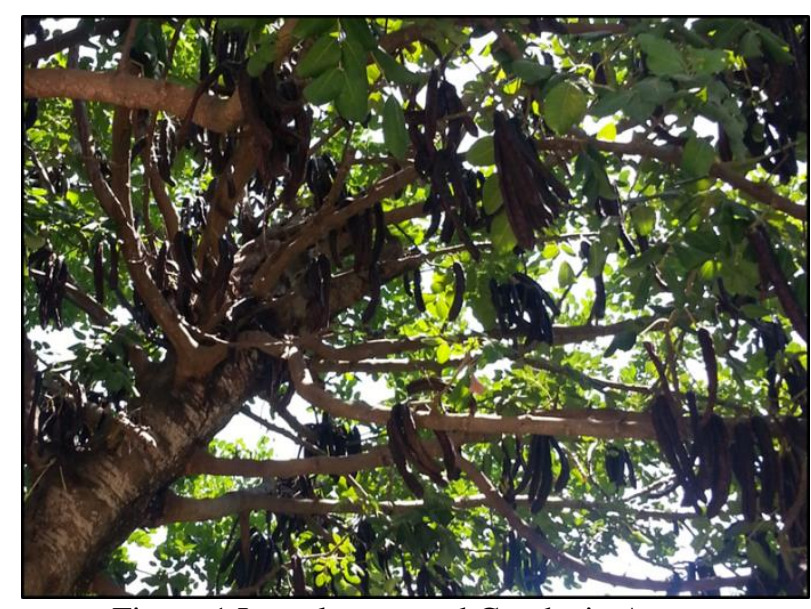

Figure 1 Largely matured Carobs in August

(Antalya/Adrasan)

The carob's canopy is wide and its diameter can reach $15 \mathrm{~m}$. Its leaves are 3-5 cm long and elliptical, while its flowers are small and greenish red. These flowers form clusters of $50-60$. The fruits are bright green at first and turn to brown, then to black after being matured. The fruits of the wild species are short and matte, while the fruits of cultured species are bright, longer and closer to black. The fruits are curvy, straight, with packed seeds. The length of the economically valuable ones changes between 5 and $30 \mathrm{~cm}$. Since the fruits have a very tough peel, it is very difficult to propagate from its seeds (Günal, 1999). However an external intervention (by humans or animals) may break the fruits and allow the seeds to germinate. Each fruit has an average of $10-15$ seeds.

Carob fruits start maturing around June - July, and are harvested between September and November - December. Harvesting the fruits by hitting the tree with long sticks affects the productivity in the next year. Like with the olive tree, harvesting by hitting with long sticks, breaks the young shoots thus, varying the productivity between years. The carob tree starts producing fruits between 5 and 10 years of age, and becomes commercially mature a 15 years. (Tunalığlu and Özkaya, 2003). Another characteristic of the plant is that its productivity and fruit quality increases every year (Alexander and Shepperd, 1974). A carob tree lives for $300-400$ years and its average productivity varies between $90-115 \mathrm{~kg} /$ year. This may increase up to $300 \mathrm{~kg}$ depending on climate and soil conditions (Gharbi, 2005; Taşligil, 2011).

Carob fruits consist of $90 \%$ fruit and 10\% seeds, and $91 \%$ of the fruit is dry matter. The dry matter of the fruit contains more than $50 \%$ sugar. This means that the carob fruit contains more sugar than sugar beet $(15-20 \%)$ and sugar cane (13 - $17 \%$ ) (Karkacier \& Artık, 1995; Tunalığlu \& Özkaya, 2003). As with most legumes, carob bean is also protein-rich. The protein amount of carob shoots is around $50 \%, 5.1 \%$ in the pulp and $17.8 \%$ in the seeds (Anonymous, 2016b). In terms of minerals, 100 gram of the fruit contains $42 \mathrm{mg} \mathrm{Mg}, 104 \mathrm{mg} \mathrm{Fe}$, $1100 \mathrm{mg} \mathrm{K}, 307 \mathrm{mg} \mathrm{Ca}, 13 \mathrm{mg} \mathrm{Na}$ and $0.4 \mathrm{mg} \mathrm{Mn}$; and it is stated that the fruit is also rich in vitamins A, B, B2, B3, C and D (Anonymous, 2016b). 
Carob's ecological demands are little and is generally resistant to heat and draught, while being also resistant to frost and low temperatures. Its ideal temperature is $24^{\circ} \mathrm{C}$ for intensive vegetative growth and it its grows best between $30-45^{\circ} \mathrm{C}$ (Taşligil, 2011). In general, the average annual temperature in areas where the carob tree grows in Turkey rarely drops under $20^{\circ} \mathrm{C}$. The fruits start maturing between June and July, as the temperature rises above $24^{\circ} \mathrm{C}$ (Grados and Cruz, 1996). As seen in Table 1, the temperature data for the areas where carob is grown commercially in Turkey shows that the temperature doesn't drop below $25^{\circ} \mathrm{C}$ in June except in Muğla and
Burdur. From October to November, when the harvest starts, the temperature doesn't fall below $0^{\circ} \mathrm{C}$ (Table 1). The fact that the average maximum temperatures in the same areas are around $35^{\circ} \mathrm{C}$ also makes it ideal for carob growth. The fruit of the heat- and light-demanding tree reaches its highest quality in places where ideal temperature conditions are met. Carob is resistant to temperatures up to $40^{\circ} \mathrm{C}$ and the amplitude where it grows shouldn't rise above $20^{\circ} \mathrm{C}$. However, carob is easily affected by low temperatures. It starts being affected at $4^{\circ} \mathrm{C}$, and actual damage sets in after $-7^{\circ} \mathrm{C}$ (Turkish State Meteorological Service, 2015).

Table 1 Temperature $\left({ }^{\circ} \mathrm{C}\right)$ and Precipitation $(\mathrm{mm})$ Values for the Areas in Turkey where Carob is Grown the Most.

\begin{tabular}{|c|c|c|c|c|c|c|}
\hline & Mersin & Antalya & Adana & Muğla & Osmaniye & Burdur \\
\hline January & 10.1 & 9.9 & 9.6 & 5.5 & 8.6 & 2.7 \\
\hline February & 10.9 & 10.4 & 10.5 & 6.1 & 9.8 & 3.8 \\
\hline March & 13.7 & 12.7 & 13.5 & 8.5 & 12.7 & 7.0 \\
\hline April & 17.5 & 16.2 & 17.5 & 12.5 & 16.8 & 11.6 \\
\hline May & 21.4 & 20.5 & 21.7 & 17.6 & 21.2 & 16.5 \\
\hline June & 25.2 & 25.3 & 25.6 & 22.9 & 25.2 & 21.2 \\
\hline July & 27.9 & 28.4 & 28.1 & 26.3 & 27.9 & 24.7 \\
\hline August & 28.4 & 28.2 & 28.5 & 26.1 & 28.4 & 24.5 \\
\hline September & 25.6 & 24.8 & 25.9 & 21.7 & 25.3 & 20.0 \\
\hline October & 21.1 & 20.0 & 21.3 & 15.9 & 20.5 & 14.3 \\
\hline November & 15.7 & 14.9 & 15.5 & 10.5 & 14.0 & 8.6 \\
\hline December & 11.7 & 11.4 & 11.2 & 7.0 & 9.8 & 4.3 \\
\hline Total* & 588.4 & 1074.6 & 654.4 & 1169.4 & 834.8 & 426.9 \\
\hline
\end{tabular}

*Yearly Total Precipitation Avg. (mm), (Source: Turkish State Meteorological Service)

The plant is very resistant to draught with its deep root system (16 - $20 \mathrm{~m}$ ) (Anonymous, 2016). Thus, it can produce fruits in very dry conditions. In terms of its yearly average water demands, while $250-550 \mathrm{~mm}$ is ideal, it can also handle $100 \mathrm{~mm}$ precipitation (Grados and Cruz, 1996; Demirtaş, 2007). According to the climate data from carob production centers in Turkey, the average annual precipitation values are $588.4 \mathrm{~mm}$ in Mersin, $1074.6 \mathrm{~mm}$ in Antalya, $654.4 \mathrm{~mm}$ in Adana, $1169.4 \mathrm{~mm}$ in Muğla, $834.8 \mathrm{~mm}$ in Osmaniye and 426.9 $\mathrm{mm}$ in Burdur (Table 1). Based on this data, it can be stated that the total precipitation averages are ideal for healthy carob growth. Additionally, the fact that precipitation in those areas happens in short, intense periods allows satisfying the plant's water demands only in certain periods in the year. Thus, the shortness of the rainy days that the plant takes up water is very important. Indeed, the number of rainy days is 72.2 in Mersin, 77.3 in Antalya, 96.3 in Muğla and 81.6 in Adana (Turkish State Meteorological Service, 2015).

Carob is not selective in terms of soil, and is also not demanding in this respect. Poor soils are especially ideal for the plant's growth, and neutral, low-acidity, light soils are very suitable. Carob doesn't like moist soils and mostly likes salty, sandy and alluvial soils. Terra-rossa soil that is very widespread in the Mediterranean shores of Turkey are the most suitable soil for carob growth. Moreover, carob likes red soils that are washed from lime due to various reasons, can also grow on rendzina and regosol soils.
Although all this structural and ecological demands were determined, there is a limited number of studies on the genetic resources of carob. There are only 93 varieties in 9 collection gardens that collect carob's genetic resources in the world, and wild species are very rare among those. Additionally, these collections lack species from Turkey, the actual root of the carob tree. In this regard, carob varieties must be well identified and a data bank for carobs must be created in Turkey. The limited studies conducted in Turkey have identified 3 varieties and these are Wild, Pulpy and Sisam (Keleş et al. 2014). Wild Carob constitutes $70 \%$ of the reserve, while the Pulpy type is spread in a wide area, especially on the Mediterranean shore. Sisam is generally encountered around the Aegean region (Taşligil, 2011). The most recent study on carob is the study conducted by Pekmezci et al. (2005) on 8 wild and 5 cultured varieties in Adana and Mersin.

\section{Geographical Distribution of Carob Tree in Turkey}

While there is no certain information on the native area of carob, most researchers point to the east of the Mediterranean basin. De Candolle (1883) and Vavilov (1951) indicated Turkey and Syria as its native area; while Schweinfurth (1894) stated that the plant dispersed around the world from Yemen's mountains; Zohary (1996) specified the Arabian Peninsula along with ryegrass, daphne and myrtle. Thus, it may be stated that the main ecological native area of carob is the areas where 
the wild species of the plant are encountered including Turkey. Thus, Turkey, all of Cyprus, Syria, Lebanon, Israel, Egypt and southern Jordan can be considered the native areas of carob. Today, carob is spread all over North Africa, after being brought and adapted to Tunisia, Libya, Northern Algeria, Northern Morocco and the Atlantic shores by Arabs.

Carob in Turkey is dispersed on all the Aegean and Mediterranean coast starting at Urla, İzmir. It sometimes forms forests on the southern hillsides of the Taurus Mountains, and reaches Samandağ, Hatay. Its largest concentration is found in the belts between Antalya Silifke, and Antalya - Alanya. Carob can reach the internal parts of the country from the coast through valleys. It was observed $90 \mathrm{~km}$ inland in Kozan (Adana) (Figure 2). The plant can survive up to $800 \mathrm{~m}$ in Turkey since it finds the ideal conditions, and carob trees were found at $900 \mathrm{~m}$ in Antalya. The carob tree is found in these areas not in the form of forests, but individually or in small groups that consist of 5-6 individual trees. Historical records show that in its native areas, it has been used for thousands of years (Shepperd, 2008).

\section{Carob Production in Turkey}

Although global carob production is decreasing every year, the demand for carob products increases. Thus, traditional carob producers are taking some measures and making some efforts. Important developments happened in Turkey especially in recent years, and our country started producing $10 \%$ of the world's carob. This section discusses the regional status of carob in Turkey, the tree reserve, the production amount and its geographical distribution, its productivity and finally carob products and their economic status.

Carob area and number of trees: Carob is a plant that grows naturally in the areas where the Mediterranean climate is dominant. Thus, in its ecological distribution areas, trees that exist without the need for culture are used for production. However, since the demand for carob significantly increased and its areas of use expanded in the recent years, it caused an increase in efforts to domesticate the plant. Carob orchards are being established in Erdemli (Mersin) to meet the external demand. In recent years, closed carob orchards were established especially in Kozan (Adana). As seen in Figure 3, which is prepared to show the changes concerning carob, while the field narrowed significantly at the end of 1990s and the beginning of 2000s, a general upwards trend is seen until 2014, albeit with small fluctuations. In 2014, the carob area reached its maximum (631 ha) but decreased to 524 ha in 2015. Fires were the main reason of this decrease. Additionally, 30.000 ha of carob trees were planted in the context of Carob Action Plan that was completed in 2015.

A matter that must be mentioned in the context of carob's regional distribution is that the trees are not always in groups in all the regions and live individually. This causes some difficulties in the calculation of carob distribution and area. For example, although Tarsus,
Mersin is the third most carob beans producing area in Turkey, there is no concentrated carob areas in the region. Similarly, there are no carob tree concentration areas in Muğla. Lack of closed orchards and carob plantations that are modernly maintained and cultured also causes the potential of Turkey to be underused.

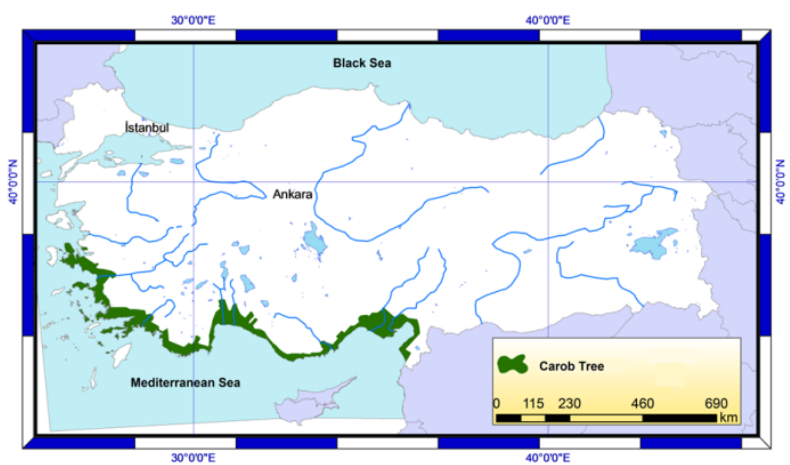

Figure 2 Natural Distribution of Carob Tree in Turkey

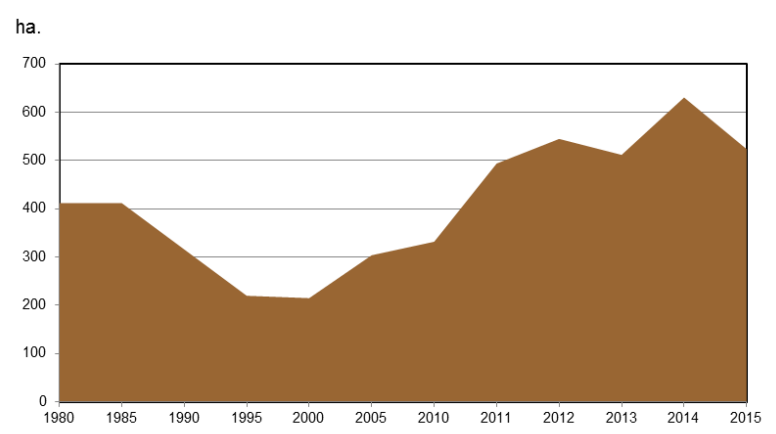

Figure 3 Total Carob Tree Area in Turkey for Selected Years

\section{Amount}

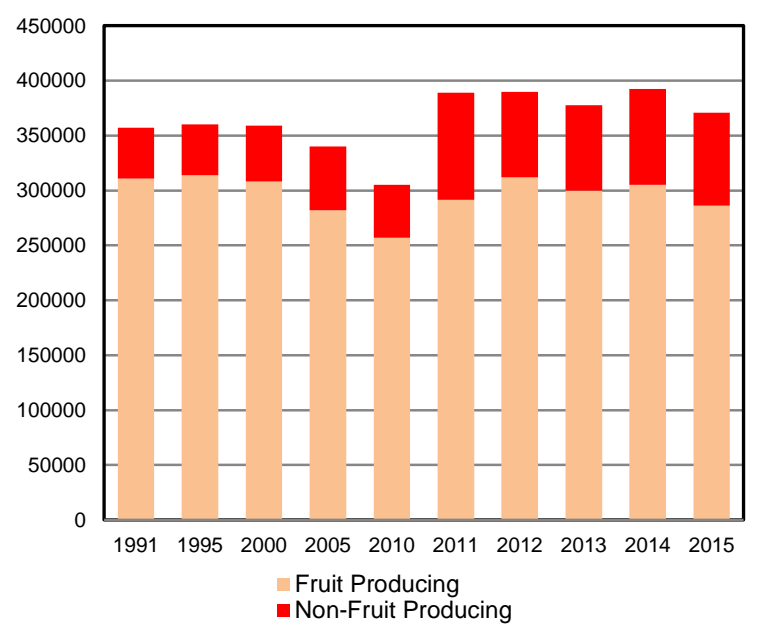

Figure 4 Number of Fruit Producing and Non-Fruit Producing Carobs in Turkey for Selected Years (Source: Turkstat, 2016.)

Since carob trees in Turkey's total forest area are widely distributed in small groups, it has not been possible to count them like other forest trees. The known carob count only includes the economically used trees and the real number of carob trees is much higher than this number. Figure 4 shows the number of economically used 
carob trees that produce fruits and that doesn't produce fruits separately and it can be seen that there was no significant changes in the total tree count since 1991. The number of non-fruit producing trees in all the years in the figure is very small compared to the total. The number of carob trees that was less than 400 thousand but the number of economically viable trees is expected to gradually increase due to the 26.000 newly planted trees and 2.600 trees that were maintained between 2006 and 2015 within the scope of the Carob Action Plan. Additionally, deviations in predictions occur due to the forest fires that cause widespread destruction in the carob regions. Although carob is more fire-resistant than most trees, the fact that the plant cannot form a dense forest or group, and that individual trees cannot resist a fire also makes developments in this area more difficult.

The distribution of trees in cities shows that Mersin, which has always been the largest carob producer in Turkey has the first place with 147.760 trees. Mersin is followed by Antalya (137.002), Adana (88.920), Muğla (12.193), Osmaniye (5.000), Burdur (1.550) (Turkstat, 2016).

Carob beans production: Carob beans production, like olive production, has a cycle of a good year followed by a bad year. This is mainly due to the harvest practice of hitting the tree with a stick. Hitting with sticks breaks young shoots and cause bad development in the next year. Moreover, as seen in table 2, carob production in Turkey varies between $14-15$ thousand tons, and a relative stability is achieved in this area. However, carob production around the world is regularly decreasing (except in 2011). Despite this decrease, Turkey's relative stable production caused an increase its share in global carob production. Accordingly, Turkey's share that was $4.2 \%$ in 1985, neared $10 \%$ in 2013 (Table 2). The successful efforts in recent years allow us to foresee that this ratio will increase. Another matter that needs to be discussed is that, although carob production seems stable, there is a significant increase in carob products production (gum, flour, molasses, etc.). This increases Turkey's carob exports every year.

In 2013, 145.389 tons of carob was produced in 13 countries, and Spain was the largest producer with 40.000 tons. Spain was followed by Portugal (23.000 tons), Greece (22.000 tons), Morocco (20.500 tons) and Turkey with 14.261 tons (FAO, 2016). The production values of other countries are below 10 thousand tons.

The distribution of carob production in Turkey according to cities and districts shows that southern hillsides of the Taurus Mountains and valleys are the areas that most carob trees are present. The production gradually decreases towards the western Mediterranean coast. As of 2014, economical production of carob happened in 36 districts of 6 cities in Turkey. In one city and two districts, carob areas were established but commercial production did not start yet. In terms of production Mersin is the largest producer and production goes on in 9 districts. In 8 districts of Mersin, the number of trees is above 1000 and these areas supply $52 \%$ of
Turkey's total production (Turkstat, 2016). The largest producers are the Silifke (3.705 tons) and Tarsus (1.831) districts. Mersin is followed by Antalya with its 5.183 tons of production. 12 districts in Antalya produce carob and the number of trees in 4 districts is above 10.000. In terms of production, Alanya (2.363 tons), Gazipaşa (1.108 tons), Demre (595 tons) and Finike (537 tons) are the largest producers. In Adana, 1.114 tons of carob were produced in the same year and in 5 districts production is continuing. In Sarıçam and Imamoğlu districts, new carob areas were established. Especially in recent years, there was a planned and intense effort in Adana on carob production. Carob orchards were established in all the districts of the city, and modern orchards were established especially in Çukurova and Kozan. Accordingly, Kozan (615 tons) and Çukurova (231 tons) were the largest producers in the city. As the newly planted trees start producing fruits, Adana will become more prominent in Turkey's carob production. For example, while only 50 tons of carob were produced in Karaisalı in 2014, it is the 4 th in Turkey in terms of number of trees with its 30.500 trees. Since the carob trees did not yet reach commercial maturity, production was very low but it seems possible that the district will become one of the largest producers. In 2014, 278 tons of carob were produced in Muğla, and while this was produced by 8 districts, all of the districts produced less than 100 tons. The prominent districts in terms of number of trees and production are Milas (90 tons, 5.650 trees) and Datça (50 tons, 2.000 trees). Finally, Sumbas district in Osmaniye (which is an inland province) produced 90 tons, and Bucak district in Burdur produced 68 tons of carob. These production values for 2014 will largely change by 2020. The Carob Action Plan caused 14.000 new trees to be planted only in Adana, and 5.100 trees were planted in Mersin, 5.000 in Antalya and 700 in Muğla. Moreover, Kahramanmaraş, which has no commercial production yet but has suitable conditions for carob production also received 1.800 carob trees under the project.

Table 2 Turkey's carob production for selected years

\begin{tabular}{c|ccc}
\hline Year & World Total & Turkey Total & Turkey's Share $(\%)$ \\
\hline 1980 & 362.328 & 17.000 & 4.7 \\
1985 & 304.204 & 12.725 & 4.2 \\
1990 & 268.006 & 15.000 & 5.6 \\
1995 & 240.210 & 13.000 & 5.4 \\
2000 & 221.495 & 14.000 & 6.3 \\
2005 & 170.736 & 12.000 & 7.0 \\
2010 & 170.552 & 14.172 & 8.3 \\
2011 & 181.171 & 13.978 & 7.7 \\
2012 & 166.848 & 14.166 & 8.5 \\
2013 & 145.389 & 14.261 & 9.8 \\
2014 & - & 13.985 & - \\
\hline
\end{tabular}

Source: FAO, 2016; Turkstat, 2016.

Productivity status: Carob is a plant that quickly responds to maintenance, and its productivity increases accordingly. $100-150$ individual trees are ideal for a newly established closed orchard or plantation. Moreover, $10 \times 10$ plantation will allow a 100-tree orchard and when 
economic maturity is reached, a carob tree produces $200-$ $250 \mathrm{~kg}$ products and this means 25 tons of produce from a hectare. The carob tree starts producing fruits at 5-10 years of age, and reaches economic viability at 10 years. As time passes, carob tree's productivity and fruit quality increases and it continues to be viable for over 100 years (Anonymous, 1979).

As stated before, good maintenance is important for productivity. Unfortunately, closed garden carob production is very limited and the existing production is mostly based on naturally occurring trees. The only intervention is grafting wild trees and there is no chemical application (fertilizers, pesticides, etc.) As carob flowers can be hermaphrodites, it is very important to graft the trees with both female and male flowers. Unfortunately, there is a serious lack of knowledge concerning carob grafting in Turkey. As mentioned before, as the fruits are harvested by hitting with a stick, the following year's production decreases. To prevent this, producers, especially forest villagers must be informed about manual harvesting.

Based on all these conditions, Turkey's carob productivity shows that $47.6 \mathrm{~kg}$ of product was obtained per tree in 2013, and this is well behind the potential production. Although compared to other carob producers, Turkey is in the third place after Lebanon $(92 \mathrm{~kg})$ and Cyprus $(55.7 \mathrm{~kg}$ ), the productivity is very low (Figure 6).

In addition to unstable productivity of carob due to the harvesting method, the fact that production is distributed and often based on local demand was reflected on productivity. Accordingly, annual carob productivity per tree is unstable and the productivity in 2004 that was 44 $\mathrm{kg}$ increased to $51 \mathrm{~kg}$ in 2007, decreased to $49 \mathrm{~kg}$ in 2009 but increased to $55 \mathrm{~kg}$ in 2010 , decreased to $48 \mathrm{~kg}$ in the next year. Production in the last 5 years did not rise above $50 \mathrm{~kg}$, and remained at $45 \mathrm{~kg}$ in 2015 (Turkstat, 2016).

\section{Carob Types and Trade}

Carob is used in many areas. In Turkey, it is mostly consumed as a snack and as molasses. Carob is cocoa's greatest rival in terms of its flavor. In addition to being consumed as snack and molasses, it is also being used as a cocoa alternative, thus is used in almost all the areas where cocoa is used (pastries, ice cream, chocolate milk, etc). Both the pulp and seeds of carob are being used in the industry for various purposes.

Examination of carob products and their consumption methods in Turkey reveals that the largest consumption is in the form of snacks. Carob fruits gain economic value after reaching $5 \mathrm{~cm}$. Carob fruits are left to dry for one month after harvest, and then packaged for consumption. Additionally, since carob fruit contains 18 - 20\% (16$20 \%$ in the dry fruit) of tannins, its excessive consumption causes digestive problems. However, if consumed in a balanced way, it has properties that are beneficial against digestive issues, gastritis, lung and liver problems and gum and tooth issues, while lowering cholesterol and developing muscles. (Tunalıŏlu and Özkaya, 2003). In addition to human nutrition, carob has been largely used for feeding animals.

The flour (powder) obtained by processing the pulpy parts of carob increased the interest for carob and allowed its uses to $b$ diversified. Carob contains a high amount of sugar $(52-62 \%)$ and is thus a natural flavouring (Demirtaş, 2007). Prior to the refined sugar that is used today, carob was used as a natural sweetener. Although its fruit contains a high amount of sugar, it does not increase blood sugar levels since it also contains balancing active principles (Taşlıgil, 2011). Its high sugar content and the fact that it is a healthier alternative to the much more expensive cocoa, allows it to be used in cakes, biscuits, cocoa milk, ice cream and many pastries. The preference for carob in this regard is also due to its stabilizer properties and effect that delays spoiling.

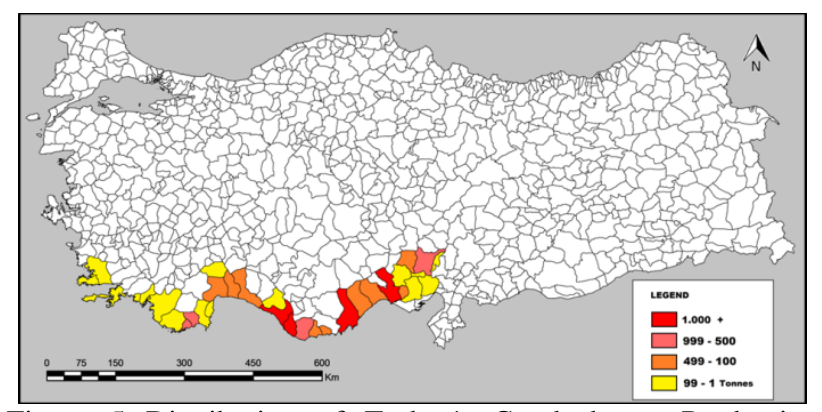

Figure 5 Distribution of Turkey's Carob beans Production According to Districts (2014)

$\mathrm{kg}$.

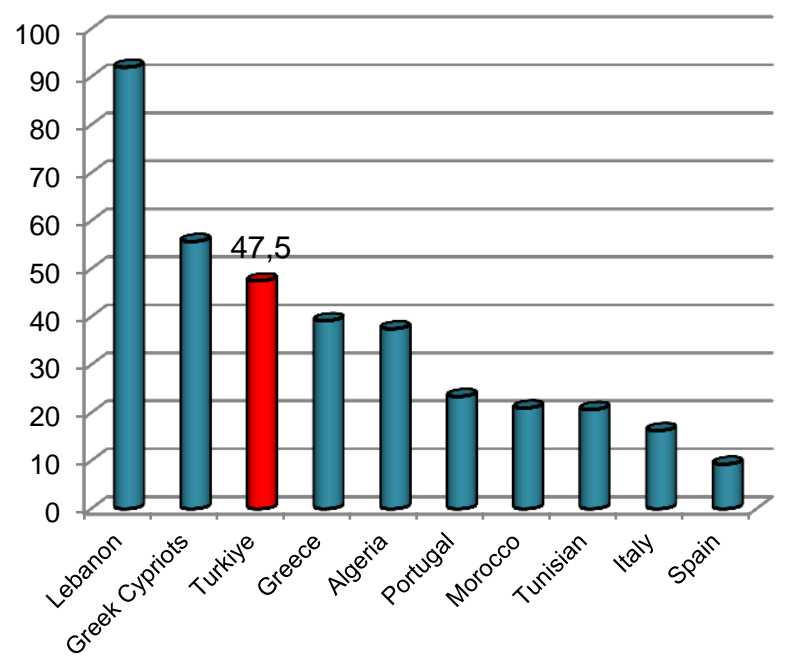

Figure 6 Carob beans Production per tree from Various Countries in 2013 (Source: FAO, 2016)

One of the traditional ways of consumption of carob in Turkey is molasses. Harnup or Carob molasses was first produced and consumed in the rural parts of the Mediterranean Region, spread out to large cities as the public learned about the benefits of carob.

The gum obtained from carob seeds is used as a stabilizer in cream cheeses, jellies, canned meat, fish and fruits, salami, sauce, syrup, ketchup and tomato paste, mayonnaise and frozen foods. Carob gum is a white 
powder and is also used in chemistry, cosmetics, textile, petroleum, plastic and ceramics industries, paper industry and carpentry in addition to food stuffs.
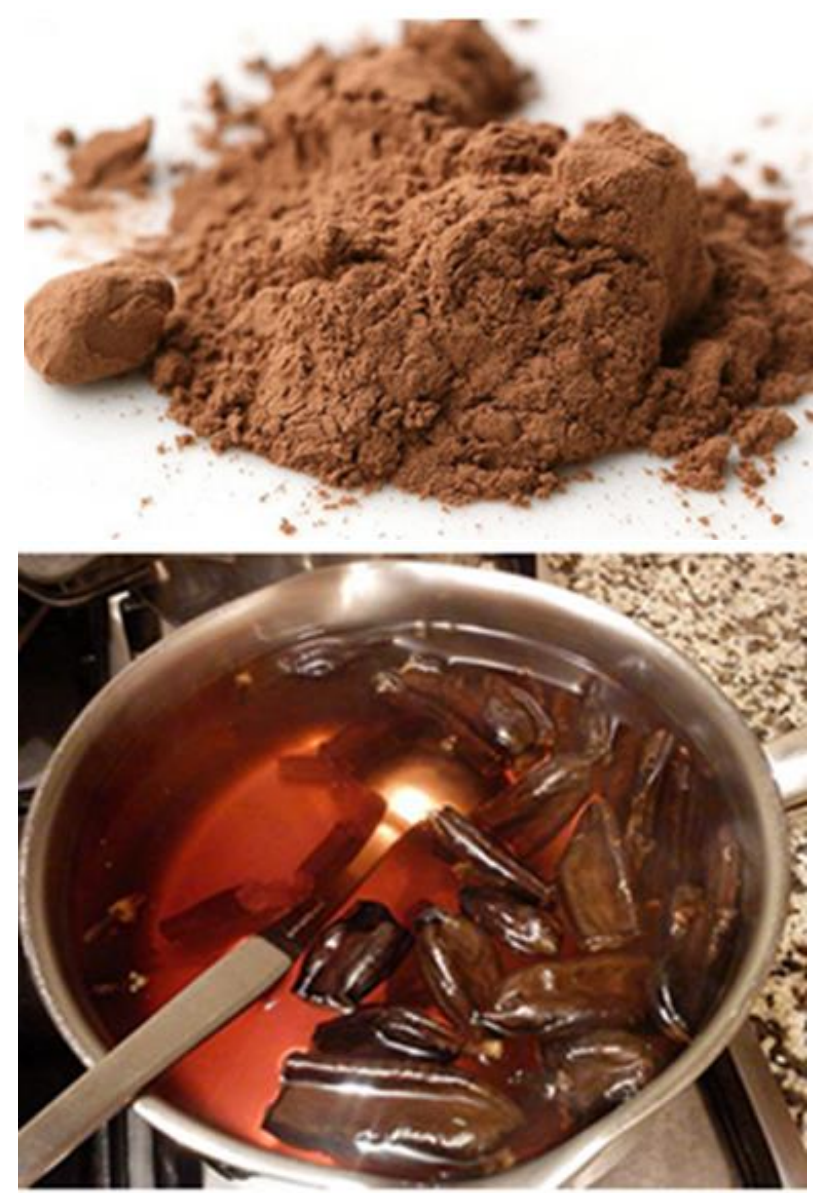

Figure 7 Carob Flour (Top) and Carob Syrup (bottom)

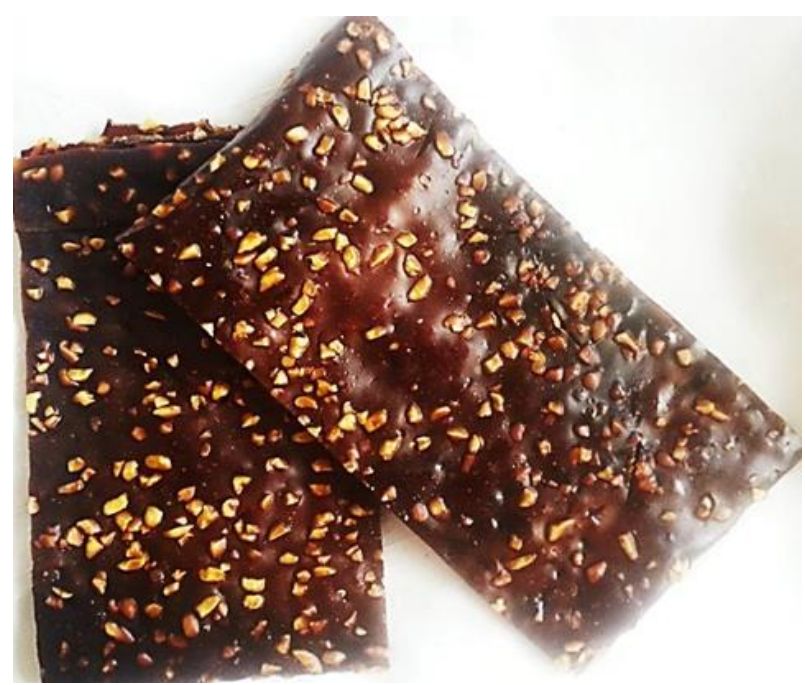

Figure 8 Dried Carob Pulp with Nuts

Another use of carob seeds is as a unit of weight. The seeds maintain their weights for a long time in nature, however long they remain out in the open. Due to this property, jewellers used to use carob seeds as a unit of weight to measure precious stones such as ruby, diamond and emerald. Each seed was considered $0.2 \mathrm{~g}$ (5 seeds make 1 gram) and the unit of weight called a "carat" today (Greek: Keration) was equivalent to a carob seed. (Battle and Tous, 1997; Ilpumbu, 2008).

In addition to products obtained from carob, the tree itself is also used for various purposes. The ability of the plant to develop better in shallow soils provides a great advantage in the fight against erosion. It must be emphasized that the natural distribution of carob in Turkey is in areas that are sensitive to erosion and that are under high risk of forest fires in summer every year. Indeed, in the Mediterranean and Aegean coasts, spreading the carob tree manually will provide an economic resource to the forest villagers and will also be beneficial in the fight against erosion, and the establishment of fire-resistant forests. Carob is also widely used in landscaping.

The commercial status of carob in Turkey reveals an unstable development in both imports and exports (Figure 9). The imports were very limited from 2000 to 2010 and consisted mainly of processed carob products. However, over 4 million $\mathrm{kg}$ was exported and this mostly consisted of raw carob and carob seeds. In 2011, imports were close to the exports, and in 2012, imports exceeded exports for the first time. The next year, our imports were decreased by $50 \%$ compared to the previous year, and our exports exceeded 3 million kg. Finally in 2014, 2.9 million $\mathrm{kg}$ was imported against 2.2 million $\mathrm{kg}$ exports. Turkey imported carob from 5 countries (Spain, Portugal, Morocco, Lebanon, and Northern Cyprus) and exported mostly to Saudi Arabia, Israel, Jordan, South Korea, Germany, Belgium, Romania and Egypt.

\section{Conclusion and Suggestions}

Carob is a plant that has been used since the Neolithic age and is still used for various purposes. It has high nutritional value; it can easily be grown in the Mediterranean climate, and is an alternative economic resource for areas that are not suitable for agriculture, thus a very attractive plant for forest villages. Although efforts are being made for many years to develop forest villages and reduce their pressure on their environment, these efforts were rarely adequate. In recent years, a heavy forestation effort is made to increase the wealth of these villages and develop them on site. In this context, General Directorate of Forestry initiated the Carob Action Plan between 2006 and 2015 to rehabilitate, maintain and rejuvenate carob trees. Many successful applications were made in many cities, especially Adana, where carob trees are grown. The economic reflections of the project will be visible after 2020. According to the results, and considering the expectations, a second action plan may be initiated between 2020 and 2025. However, these efforts should include more than just increasing the carob population. Scientific studies must constitute an important part of the activities under the Action Plan. Indeed, both the growing areas and the plant itself must be rehabilitated. For this purpose, it is very important to determine the existing carob gene sources. Identifying the 
gene sources and registering them may allow a much healthier production activity. The studies in this respect in Turkey are still very inadequate and wrong grafting by villagers creates a heavy pressure on the wild carob reserve and endangers our resources.

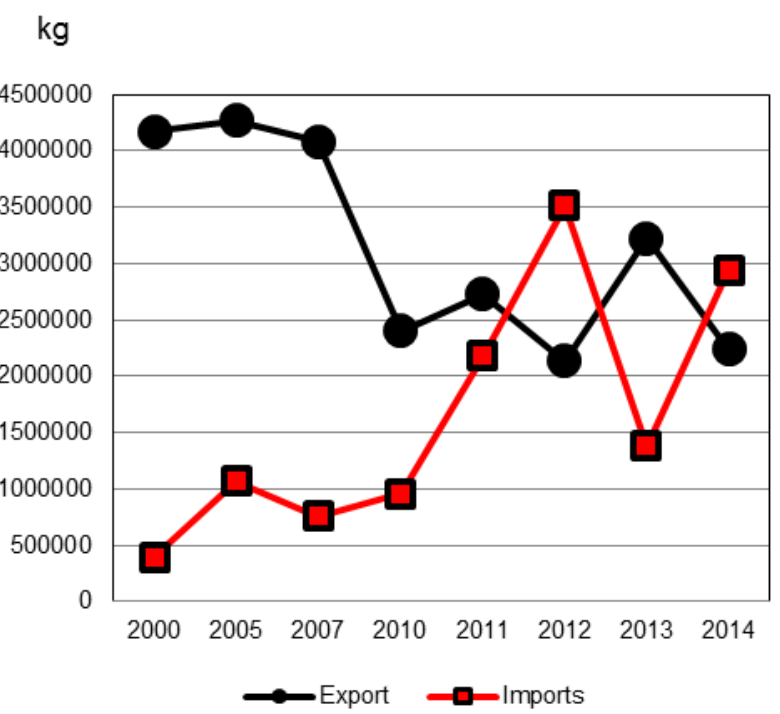

Figure 9 Carob and Carob Products Exports and Imports of Turkey for Selected Years (Source: Turkstat, 2016)

Almost all of the production is based on gathering from nature, and establishing plantation-like or closed orchards in Turkey and increasing the agricultural area and production will allow a new export product in addition to local consumption (molasses, snacks, syrups, etc.). A planned production can be done by terracing the slopes that are not suitable for agriculture and establishing orchards. A cooperation is possible with Spain, that has been professionally growing carob for many years. Additionally, it is important to plant carobs in a manner to establish forests with different trees. The fact that the plant burns late, and is ideal in the fight against erosion are very important properties.

The increasing importance of carob in Turkey and the world is due to an increased nutrition awareness in people. The demand is increasing due to the fact that the plant is a cocoa alternative. Additionally, as there is no planned growing activities in carob producing countries, production fluctuates and decreases according to the year. This drives carob's price up in international markets and causes an uncertainty in the industry. Considering the fact that Turkey's ability to meet its carob demands, a strategic planning is necessary in this context. For this purpose, Carob Regions must be determined first. 3 regions may be suggested consisting of Antalya - Mersin - Adana, Muğla - Aydın - İzmir - Burdur and Adana Osmaniye - Hatay - Kahramanmaraş. A grower representative must be assigned in all of these regions with a general grower union in Mersin must be established. Thus, quick responses can be given against problems in product marketing and development may become possible to open up new markets. As mentioned before, the variety of products obtained from carob is increased but promotion and entering new markets are still areas that need development. Especially carob flour and, snacks that are made with carob flour that cater mostly to the young population (biscuits, cakes and other cocoa products) are also healthier, so have a highly competitive advantage in the market. Moreover, promotion of local products such as molasses, in addition to traditional products with added carob (Turkish Delight, cezerye, paste) gain added value and will increase the income of Turkey, especially the forest villagers, from carob. In addition to traditional products, determining the carob gene sources will facilitate the identification of geographical landmark products. Our potential geographical landmarks concerning the carob presence in Turkey are Mersin Carob, İzmir Carob, Turk Carob, and Mersin Harnup Molasses.

Finally, increasing the farmers' awareness is one of the key requirements of carob production and commerce in Turkey. Farmer training programs must be established to inform farmers concerning grafting wild carobs, harvesting manually or with machines instead of sticks, establishing closed carob gardens and the points to consider in the production of organic carob.

\section{References}

Alexander RR, Shepperd WD. 1974. Ceratonia siliqua L., Carob, In: Schopmeyer CS, tech. coord. Seeds of woody plants in the United States. Agric. Handbk. 450. Washington, D.C. USDA Forest Service: 303-304.

Anonymous. 1979. Tropical Legumes: Resources for the Future, National Academy of Sciences, pp. $109-116$, Washington, D.C.

Anonymous. 2016a. Keçiboynuzu (Harnup) Eylem Planı (2006 2015), T.C. Çevre ve Orman Bakanlığı, Silvikültür Daire Başkanlığı, pp. 25, Ankara.

Anonymous. 2016b. Carob (Ceratonia siliqua), http://www.feedipedia.org/node/320 (Last access: 12.09.2016).

Batlle I, Tous J. 1997. Carob Tree. Ceratonia siliqua L. Promoting the Conservation and Use of Underutilized and Neglected Crops. 17. Institute of Plant Genetics and Crop Plant Research, Gatersleben/International Plant Genetic Resources Institute, Rome, Italy.http://www.bioversityinternational.org/ uploads/tx_news/Carob_tree_Ceratonia_siliqua_L._347.pdf (Last access: 12.09.2016).

Batlle I. 1997. Current Situation And Possibilities of Development of The Carob Tree (Ceratonia siliqua L.) in the Mediterranean Region, Basılmamış FAO Raporu, Rome/Italy.

Bronstein Lynn. 2013. The Literary Cookbook: The Day of the Locust, Boryanabooks, Publisher of Ebooks and Commentary, http://boryanabooks.com/?p=2993 (Last access: 12.09.2016).

Ceylanlı N. 1962. Harnup (Keçiboynuzu) Yetiştirilmesi Bitkisel Değeri ve Ekonomik Önemi, Tarım Bakanlığı, Mesleki Kitaplar Serisi, pp. 36, Ankara.

De Candolle A. 1883. L'origine des Plantes Cultivées. Balière, Paris.

Demirtaş Ö. 2007. Keçiboynuzu (Ceratonia siliqua) Çekirdeklerinden Gam Üretim Yollarının Araştırılması, Basılmamış Yüksek Lisans Tezi, Çukurova University Institute of Natural And Applied Sciences, pp. 48, Adana.

FAO. 2016. Crops Statistics, http://faostat3.fao.org/download/ Q/QC/E (Last access: 12.09.2016).

Ghrabi Z. 2005. A Guide to Medicinal Plants in North Africa, IUCN Centre For Mediterranean Cooperation Published, pp. $79-81$, 2005, Malaga / İspanya. 
Grados N, Cruz G. 1996. New Approaches to Industrialization of Algarrobo (Prosopis pallida) Pods in Peru, pp. 3.25 - 3.42. In: Prosopis. Semiarid Fuelwood and Forage Tree; Building Consensus for the Disenfranchised. (Eds.) European existentialist philosophers and authors Felker and J. Moss. Center for Semi-Arid Forest Resources Kingsville, Texas/USA.

Günal N. 1999. Keçiboynuzu (Ceratonia siliqua L.)'nun Türkiye'deki Coğrafi Yayılışı, Ekolojik ve Floristik Özellikleri, Marmara Geographical Review, No: 2, pp. 60 - 74, 1998 1999, İstanbul.

Iipumbu L. 2008. Compositional Analysis of Locally Cultivated Carob (Ceratonia siliqua) Cultivars And Development of Nutritional Food Products For a Range of Market Sectors, Basılmamış Yüksek Lisans Tezi, December 2008, Stellenbosch, South Africa.

İbrahim Abdüsselam Paşa. 2008. Yemen Seyahatnamesi ve Bitkisel Coğrafyası, Derleyen: Leyla Batu Pekcan, Gri Publishing: 65, December 2008, İstanbul.

Karkacıer M, Artık N. 1995. Keçiboynuzunun (Ceratonia siliqua L.) Fiziksel Özellikleri, Kimyasal Bileşimi ve Ekstraksiyon Koşulları, The Journal of Food, Vol. 20, Issue: 3, pp. 131 - 136, Ankara.

Keleş H Ulusoy R, Bilir N. 2014. Selection Protection and Importance of Gene Conservation Areas in Wild Carob Tree (Ceratonia siliqua L.), 3rd International Non-wood Forest Products Symposium, 8 - 10 May 2014, pp. 71 - 79, Kahramanmaraş.

Keleş H, Bilir N. 2015. Interaction of Growth And Reproduction Characteristics in Carob Tree (Ceratonia siliqua L.) Populations, Agriculture \& Forestry, Vol. 61, Issue: 4, p. 369 377.

Özdem MA. 2012. Dünya ve Türkiye'de Kuru Baklagiller, TEPGE Bakış, 1303-8346/7, p. 9, Ankara.

Pamay B. 1992. Bitki Materyali I. Ağaç ve Ağaççıklar, Uycan Publication, İstanbul.

Pekmezci M, Erkan M, Adak N, Gübrük H, Onus N, Karaşahin I, Eti S, Biner B. 2005. Doğu Akdeniz Bölgesinde Yabani ve Kültür Formunda Yetişen Keçiboynuzu Tiplerinin Seleksiyonu, Journal of Bahçe, No: 34, Issue: 2, p. 73 - 82 Yalova.

Pekmezci M, Gübbük H, Eti S, Erkan M, Adak N, Onus N, Karaşahin I, Biner B, Adak N. 2008. Batı Akdeniz ve Ege Bölgesi'nde Yabani ve Kültür Formunda Yetişen Keçiboynuzu Tiplerinin Seleksiyonu, Mediterranean Agricultural Sciences, Vol. 21, No. 2, p. 145 - 153, Antalya.
Schweinfurth G. 1894. Sammlung Arabisch-aethiopischer Pflanzen, Ergebnisse von Reisen in den Jahren 1881, 1888-89, 1891-92. Bull. Herb. Boissier 2: 1-114.

Shepperd WD. 2008. Fabaceae - Pea Family Ceratonia siliqua L. Carob, USDA FS Agriculture Handbook 727 - The Woody Plant Seed Manual, pp. $371-373$.

Şahin M, Sabuncu R, Cengiz Y. 2004. Keçiboynuzunun (Ceratonia siliqua L.) Yetişstirilmesi, Teknik Bülten No: 21, T.C. Çevre ve Orman Bakanlığı Yayın No: 228, Müdürlük Yayın No: 023, Year: 2004, Antalya.

Taşlıgil N. 2011. Keçiboynuzu (Ceratonia siliqua L.)'nun Coğrafi Yayılışı ve Ekonomik Özellikleri, ODÜ Sosyal Bilimler Enstitüsü Sosyal Bilimler Araştırmaları Dergisi, Cilt: 2, pp. 252 $-266$.

Tunalığlu R, Özkaya MT. 2003. Keçiboynuzu, Tarımsal Ekonomi Araştırma Enstitüsü - BAKIŞ, Vol. 3, Issue: 5, pp. 4, Ankara.

Turkstat. 2016. Crops Statistics, http://www.turkstat.gov.tr/Start.do (Last access: 12.09.2016).

Vavilov NI. 1926. Centres of Origin of Cultivated Plants. Bulletin of Applied Botany, Genetics and Plant Breeding, 16: 1-248.

Vavilov NI. 1951. The Origin, Variation, Immunity, and Breeding of Cultivated Plants Translator: K.S. Chester. The Ronald Press Co., New York.

Yıldız A. 1995. Keçiboynuzunun (Ceratonia siliqua L.) Değişik Yöntemlerle Çoğaltılması Üzerinde Araştırmalar, Basılmamış Doktora Tezi, Çukurova Üniversitesi Fen Bilimleri Enstitüsü, Adana.

Yıldırım Hİ, Kargıoğlu M. 2015. Alanya ve Gazipaşa (Antalya)'da Doğal Keçiboynuz (Ceratonia siliqua L.) Pekmezinin Üretimi ve Kullanımı, Afyon Kocatepe University Journal of Sciences and Engineering, Vol. 15, p. $10-16$.

Yaltırık F, Efe A. 1994. Dendroloji, İstanbul University, Faculty of Forestry Publishing, No: 431, 1994, İstanbul.

Zohary D. 1996. Domestication of the Carob Tree, II. International Carob Symposium, Cabanas-Tavira / Portugal. 